\title{
IRSETCONF
}

\section{ANALYSIS OF MULTI-DISC GRINDING PROCESS OF RICE GRAINS}

\author{
Weronika Kruszelnicka \\ Faculty of Mechanical Engineering, University of Science and Technology in Bydgoszcz
}

\begin{abstract}
Grinding process is one of the major steps in production of powders for food, chemical and energy use. It still characterized by insufficient operation indicators such as efficiency, energy consumption, quality of product. Bering it in mind the aim of the work is to analyze the multi-disc grinding process of grainy biomass and search the dependence between operation parameters, like angular speed of cutting edge, feeding speed, and operation indicators. Research problem formulated as a question: how the angular speed of cutting discs affects real efficiency, energy consumption and grinding product quality? To resolve the problem an experiment on five disc mill was done considering variable disc angular speed and measuring in real time the changes of power demand and angular speed of each disc, product weight increase. The test allows to say that disc speed has an influence on the energy consumption and the product quality. It was observed that the lower disc speed the lower energy consumption and bigger the product particles. For real efficiency, based on the results obtained, the dependence on the angular discs speed cannot be clearly determined.
\end{abstract}

Keywords: comminution; biomass; product quality; efficiency; energy consumption 


\section{IRSETCONF}

\section{Introduction}

From mechanical point of view grinding, milling, crushing are terms for deliberate actions of breaking a material structure by two elements moving relative to each other (Austin \& Trass, 1997; Bergman, 2005; Brożek \& Naziemiec, 2012; Flizikowski \& Sadkiewicz, 2013; Loh et al., 2015; Miu et al., 2006; Niedzwiecki, 2012). Grinding operations are one of most popular processes in preparation of raw materials for their further processing, for example: burning, compressing, fermentation, suspensions preparation etc. It plays a significant role in energy industry (coal crushing). The importance of the research on comminution is expressed by its intensity and actions aimed at improving the process and the grinding product quality and has been described in various publications including (Austin \& Trass, 1997; Gil et al., 2015; Johnson, 2006; Liu et al., 2015; Liu et al., 2016; Tamura et al., 2014).

Research forms the base for improvement, development of innovative design solutions, meeting the market and the users' (customer) requirements in terms of efficiency, operation and maintenance cost, energy consumption and quality (Kłos, 2016; Macko et al., 2016). Specificity of the grinding processes application areas involves the need to provide it with some required features, which can be considered as qualitative criteria for the obtained product such as: size and shape of particles, appropriate grain size distribution, appropriate surface area obtained (Niedzwiecki, 2012).

It is not easy to know properties of the feeding material, machine and mutual relations and interactions of the grinding machine with the feeding material due to the complexity of the phenomena and processes involved in the mass flow. Attempts to structure and explain these relationships have been undertaken for many years, however, they have not brought sufficient and complete results (Dabbour et al., 2015; Dziki \& Laskowski, 2005; Mohd Rozalli et al., 2015; Shashidhar et al., 2013; Song et al., 2014; Tavares, 2004).

We need to remember that the aim of the work is to analyze the multi-disc grinding process of grainy biomass and find the dependence between operation parameters, like angular speed of cutting edge, feeding speed, and operation indicators. The research problem has been formulated in the form of the question: how does angular speed of cutting discs affect real efficiency, energy consumption and grinding product quality? To resolve the problem an experiment on five disc mill was done, taking into consideration the disc variable angular speed and measured in real time the changes of power demand and angular speed of each disc measured in a real time as well as the product weight increase. 


\section{IRSETCONF}

\section{Materials and methods}

\section{1- Materials}

The study involved 8 samples of rice, weighing $1 \mathrm{~kg}$ each. Grinded rice is used to make products such as rice floor, noodles. It can also be a valuable energy source in combustion processes. Rice wastes are most commonly used in the form of briquettes (Fang et al., 2017; Pode, 2016). The moisture content of rice grain was $13,6 \%$, and characteristic grain size $D_{80}=$ $2,16 \mathrm{~mm}$ - the size of the screen through which $80 \%$ of the grain feeds pass. The granulometric distribution of rice grains is shown in the Fig. 1.

Figure 1: Granulometric distribution of rice grains
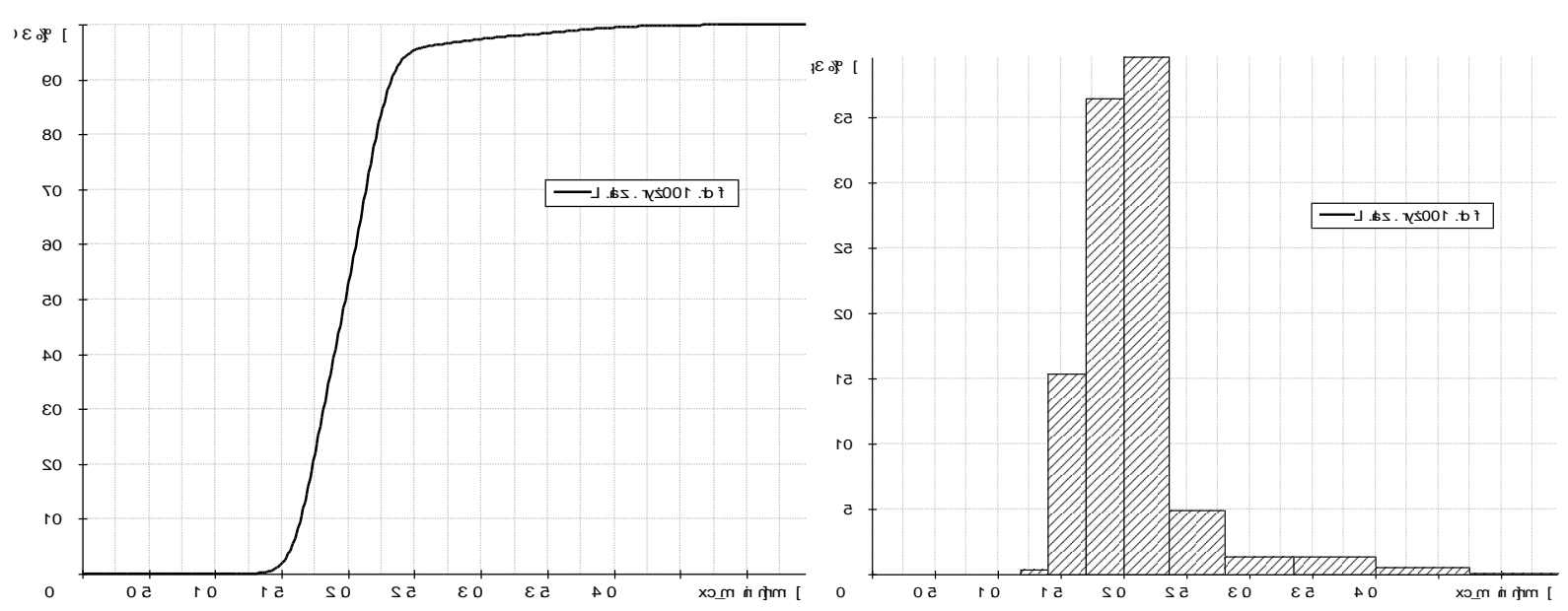

\section{Source: own research}

\section{2- Research methods}

Taking into account the main purposes of grinding process and further destination of comminuted material it is necessary to provide some special technical and operational conditions, which will guarantee (Flizikowski \& Bielinski, 2012):

- the high quality: of process, products, energy and power, wastes during grinding process,

- high efficiency in three aspects: energy (low energy consumption, drives systems efficiency, low power demand etc.), ecological (hazardous substances emission 


\section{IRSETCONF}

reduction, dust emissions reduction, environmental safety, waste recycling) and economic (low costs of consumed energy, low cost of waste utilization, low cost of O\&M),

- high harmlessness resulting from the operation of devices - local and global (influence on human health, climate safety, operator safety, low emission technology).

The main features affecting energy demand in grinding process are the mechanical (strength) parameters and the material internal structure (Dziki \& Laskowski, 2005). For a multi-disc mill, regarding the material strength parameters, the force occurring on the grinding unit shaft can be expressed as (Tomporowski, 2012):

$$
P_{R}=k_{j} \cdot v_{R}+\tau_{q} \cdot F_{R}+F_{R}^{2} \cdot v_{R} \cdot e
$$

$k_{j}-$ idling coefficient $\left[\mathrm{N} \cdot \mathrm{s} \cdot \mathrm{m}^{-1}\right]$,

$v_{R}$ - linear speed of the cutting edge $\left[\mathrm{m} \cdot \mathrm{s}^{-1}\right]$,

$\tau_{q}-$ stresses in the material during quasi-cutting [MPa],

$F_{R}$ - surface area of the grinding section $\left[\mathrm{m}^{2}\right]$,

$e$-dynamic secondary grinding index $\left[\mathrm{N} \cdot \mathrm{s}^{-2} \cdot \mathrm{m}^{-4}\right]$,

$F_{R}^{2}$ - cross-section of secondary grinding in the inter-disk gap $\left[\mathrm{m}^{2}\right]$.

Analyzing the dependence (eq. (1)) it can be said that the force, and hence the energy of grinding, depends on the time of grinding, the material properties and geometrical features of grinding unit. The quality of the product depends on the time of grinding and intensity of the material contact with the cutting edges (Flizikowski et al., 2015).

Real machine energy consumption during the grinding process is different - higher - than estimated by, for example, Kick's, Bond's laws. It's connected with phenomena that occur in the machine during the grinding process such as: energy dissipation, energy losses by elements connection, grinding irregularity. Irregularity of the machine operation results from its idle periods while successive batches of the material, dispensed by the grinding elements, pass through it. Presence of variable amount of material between the elements causes an increase in power consumption (in the case when a large amount of material is located between the cutting edges causing significant resistance of the elements) or its decrease (in the case of a smaller amount of material) (Opielak et al., 2013; Opielak \& Tomporowski, 2012). According to this statement, power consumption of the multi-disc mill includes power consumption for the idle run of the device and power consumption for grinding (Tomporowski, 2010) 


\section{IRSETCONF}

$$
N_{c P R}=N_{u}+N_{b j}
$$

where:

$N_{u}$ - useful power consumption [W],

$N_{C P R}$ - total power demand in the grinding process [W],

$N_{b j}$ - power demand for idling [W].

The work of grinding can be presented in the form of dependance (Sykutera, 2016):

$$
L_{u}=m \cdot E_{j}
$$

where:

$L_{u}$ - grinding work value [J],

$m$ - weight of feeding material $[\mathrm{g}]$,

$E_{j}$ - specific energy consumption $\left[\mathrm{J} \cdot \mathrm{g}^{-1}\right]$.

The research included determination of the grinding process effectiveness indicators, such as (Tomporowski et al., 2017):

- mass grinding efficiency $Q_{r}\left(g \cdot s^{-1}\right)$, described by the function of angular disc speed $\omega_{n}$, disc number $n$, disc diameter $D_{n}$, number of holes in the $n$-th disc $I_{n}$, diameter of holes in the $n$-th disc $d_{n}$, speed of material feeding $V_{p}$, material properties $M_{p}$ and time of grinding $t$ :

$$
Q_{r}=f\left(n, \omega_{n}, D_{n}, l_{n}, d_{n}, V_{p}, M_{p}, t\right)
$$

which in observation time $\Delta t$ of product weight changes $\Delta m$ can be calculate basing on the formula:

$$
Q_{r}=\frac{\Delta m}{\Delta t}
$$

- specific energy consumption $E_{j}\left(\mathrm{j} \cdot \mathrm{g}^{-1}\right)$, expressed as:

$$
E_{j}=\frac{N_{c P R}}{Q_{r}}
$$

- $80 \%$ grinding degree, - , described as:

$$
i_{80}=\frac{D_{80}}{d_{80}}
$$

where:

$D_{80}$ - dimension of the sieve hole, through which $80 \%$ of the feed material passes,

$d_{80}$ - dimension of the sieve hole, through which $80 \%$ of the grinding product passes.

Grinding degree $i_{80}$ was determined on the basis of a granulometric analysis and curves obtained for the feed and the product grain size distribution reading to $80 \%$ of the grains. The above characteristics provide the basis for an analysis, evaluation and intelligent development of the structure and the milling process according to the new concept of a multi-disc mill. 


\section{IRSEETCONF}

\section{3- Research plan}

The research consists of three parts: I - experiment on five disc mill, II - granulometric analysis of product and III - analysis of the results. The detailed plan was presented in the Fig. 2.

\section{4- Test stand}

The research of grinding process was carried out on a five disc mill. It consists of a feed chamber, worm feeder, grinding unit in the form of five discs with holes driven by electric motors, one motor for each disc, which facilitates controlling the angular velocities of the discs, grinding product basket, scale for measurement of the product weight changes in time and control unit (Fig. 3.). Tab. 1. shows a configuration of the discs angular speed used during the tests.

After grinding, a granulometric analysis of the grinding product was performed for each configuration. It was conducted with the use of digital image processing on the CAMSIZER device. This analysis was done to estimate the product particle characteristic size $d_{80}$ (the size of the screen through which $80 \%$ of the particles pass) and then calculate the fragmentation degree $i_{80}$.

Figure 2: Research plan

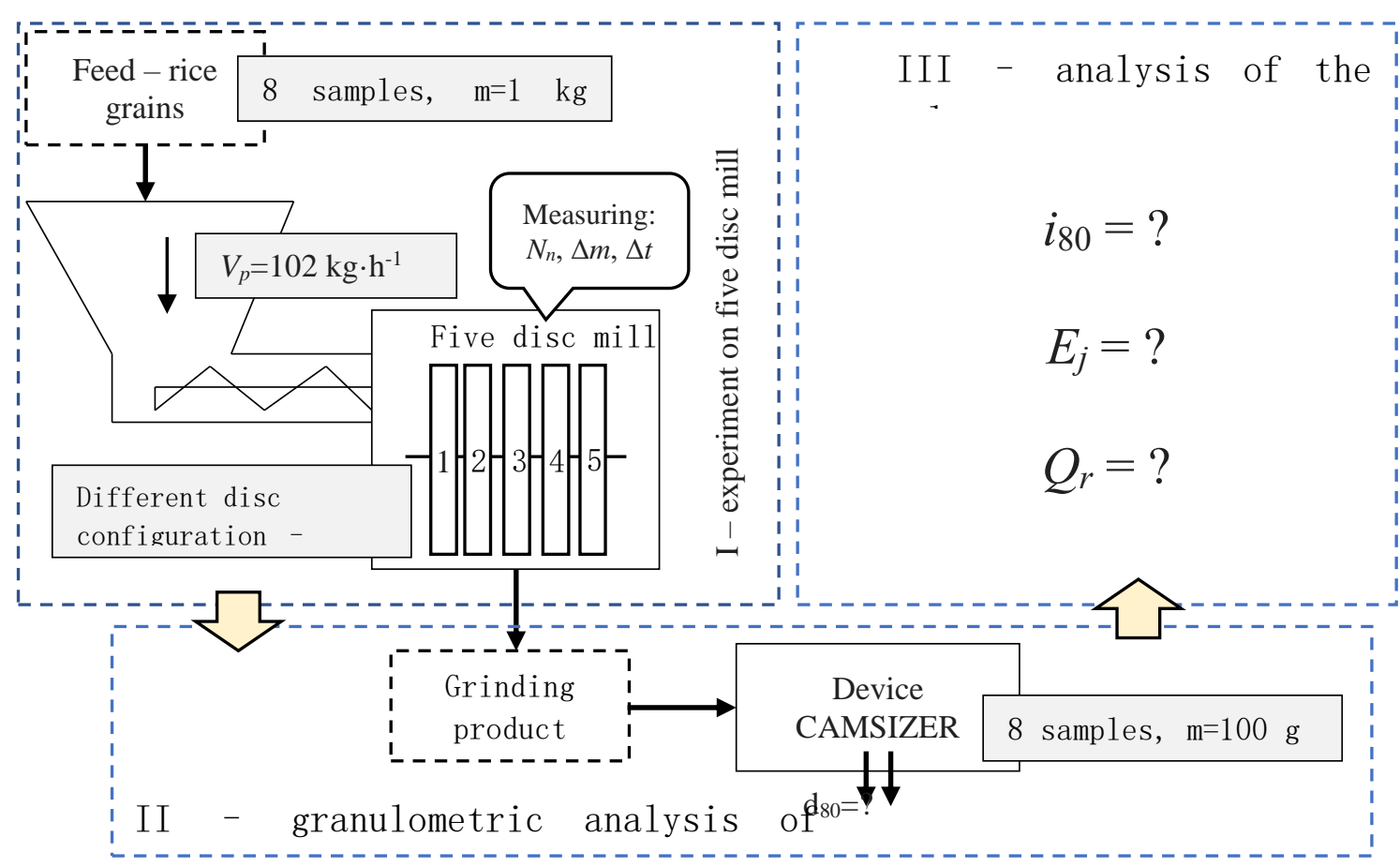

Source: own work 


\section{IRSETCONF}

Figure 3: Multi-disc mill: 1-,2-,3-,4-,5- electric motor, 6-five-disc grinding unit, 7-feeder, 8- basket for grinding product, 9- scale, 10- stepper motor, 11-control unit

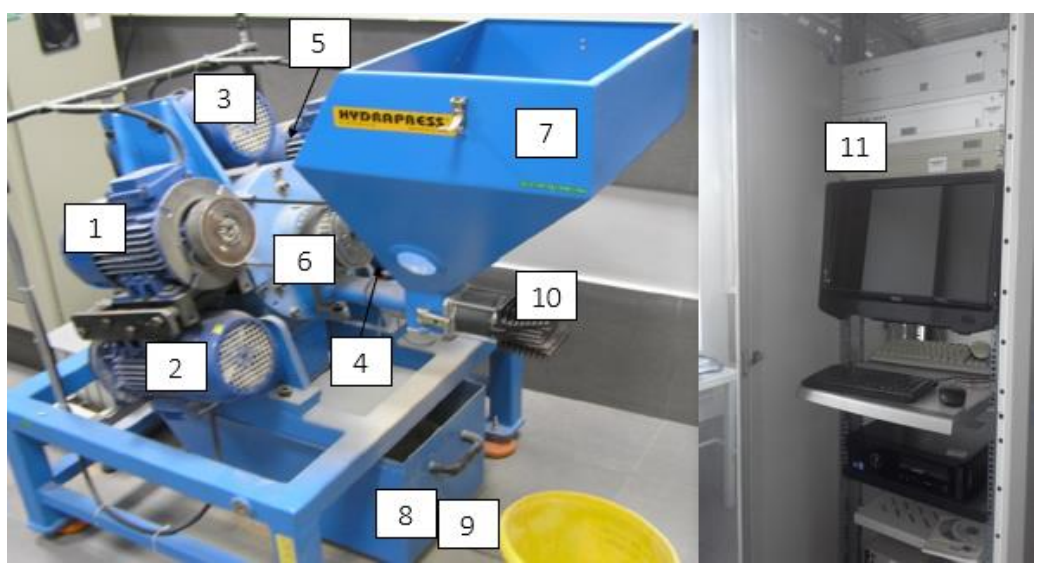

Source: own work

Table 1: Configurations of angular discs speed

\begin{tabular}{|c|c|c|c|c|c|c|c|}
\hline \multirow[b]{2}{*}{ Case } & \multirow{2}{*}{$\begin{array}{l}\text { No of } \\
\text { config. }\end{array}$} & $V_{p}$ & $\omega_{1}$ & $\omega_{2}$ & $\omega_{3}$ & $\omega_{4}$ & $\omega_{5}$ \\
\hline & & $\begin{array}{l}\mathrm{kg} \cdot \mathrm{h}^{-} \\
-\end{array}$ & $\mathrm{rad} \cdot \mathrm{s}^{-1}$ & $\mathrm{rad} \cdot \mathrm{s}^{-1}$ & $\mathrm{rad} \cdot \mathrm{s}^{-1}$ & $\mathrm{rad} \cdot \mathrm{s}^{-1}$ & $\mathrm{rad} \cdot \mathrm{s}^{-1}$ \\
\hline \multirow{4}{*}{ I } & 1 & \multirow{8}{*}{102} & 100 & 90 & 80 & 70 & 60 \\
\hline & 2 & & 90 & 80 & 70 & 60 & 50 \\
\hline & 3 & & 80 & 70 & 60 & 50 & 40 \\
\hline & 4 & & 70 & 60 & 50 & 40 & 30 \\
\hline \multirow{4}{*}{ II } & 1 & & 60 & 70 & 80 & 90 & 100 \\
\hline & 2 & & 50 & 60 & 70 & 80 & 90 \\
\hline & 3 & & 40 & 50 & 60 & 70 & 80 \\
\hline & 4 & & 30 & 40 & 50 & 60 & 70 \\
\hline
\end{tabular}

Source: own work

It was important to use discs with a different number of holes $I_{n}$ with different diameters $d_{n}$. The details about disc design are shown in Tab. 2. 


\section{IRSETCONF}

Table 2: Details of disc design

\begin{tabular}{|l|l|l|l|l|l|l|}
\hline Parameter & Unit & Disc 1 & Disc 2 & Disc 3 & Disc 4 & Disc 5 \\
\hline Disc diameter $D_{n}$ & $\mathrm{~mm}$ & 274 & 274 & 274 & 274 & 274 \\
\hline $\begin{array}{l}\text { Number of holes } \\
I_{n}\end{array}$ & pcs. & 14 & 22 & 27 & 33 & 39 \\
\hline $\begin{array}{l}\text { Holes diameter } \\
d_{n}\end{array}$ & $\mathrm{~mm}$ & 30 & 23 & 21 & 17,5 & 17,5 \\
\hline
\end{tabular}

Source: own work

\section{Results and Discussion}

During grinding, such parameters as: power demand on each disc and product weight in the basket for the grinding product time changes were recorded for each disc speed configuration. Fig. 4 presents the results of energy consumption observed for each disc in dependence on the disc speed, for case I, in Fig. 5. - the results of energy consumption observed for each disc, in dependence on the disc speed for case II. Each point of disc represents one configuration of disc speed.

Figure 4: Energy consumption for each disc in five disc mill in dependence on disc speed - case l; each point of disc represents one configuration

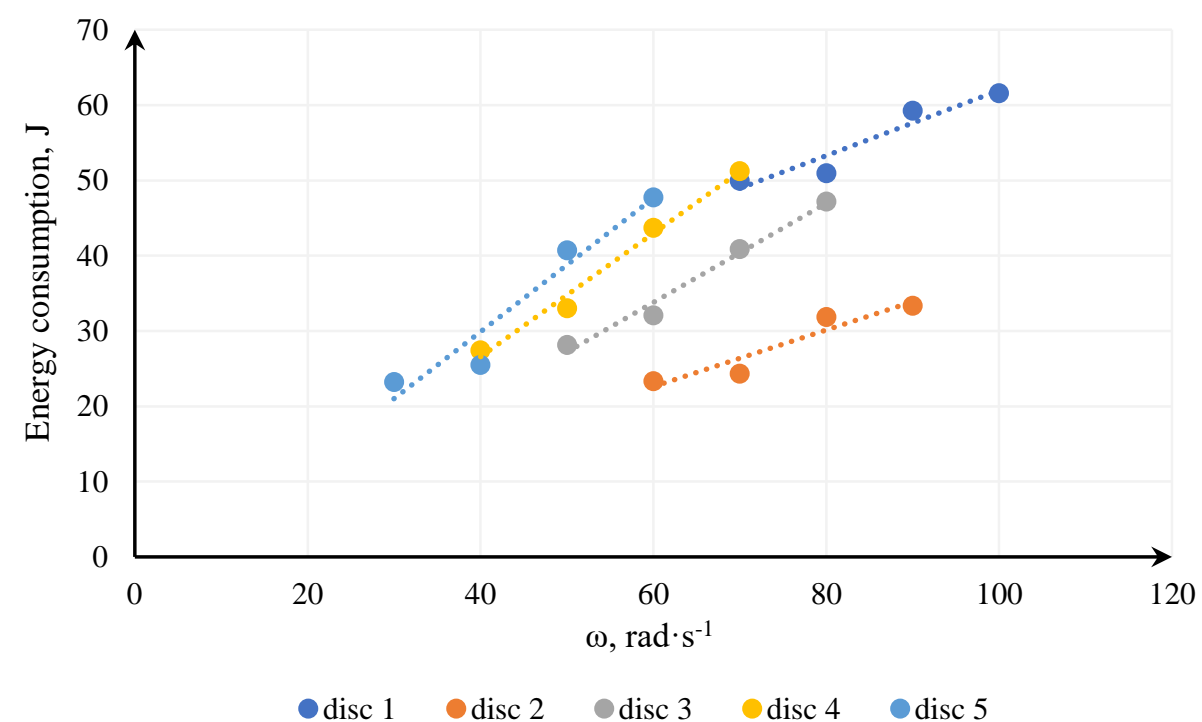

Source: own research 


\section{IRSETCONF}

Basing on the results shown in Fig. 4 and 5, it can be said that the highest energy consumption occurred for the disc with the highest speed: for the case I - first disc, for the case II - fifth disc. The lowest energy consumption for both cases occurred for second disc. The results also allow to say that as the angular velocity of the discs increases, the energy consumption during grinding increases. For case I lower energy consumption was observed on each disc than for case II.

Figure 5: Energy consumption for each disc in five disc mill in dependence of disc speed-case II; each point of disc represents one configuration

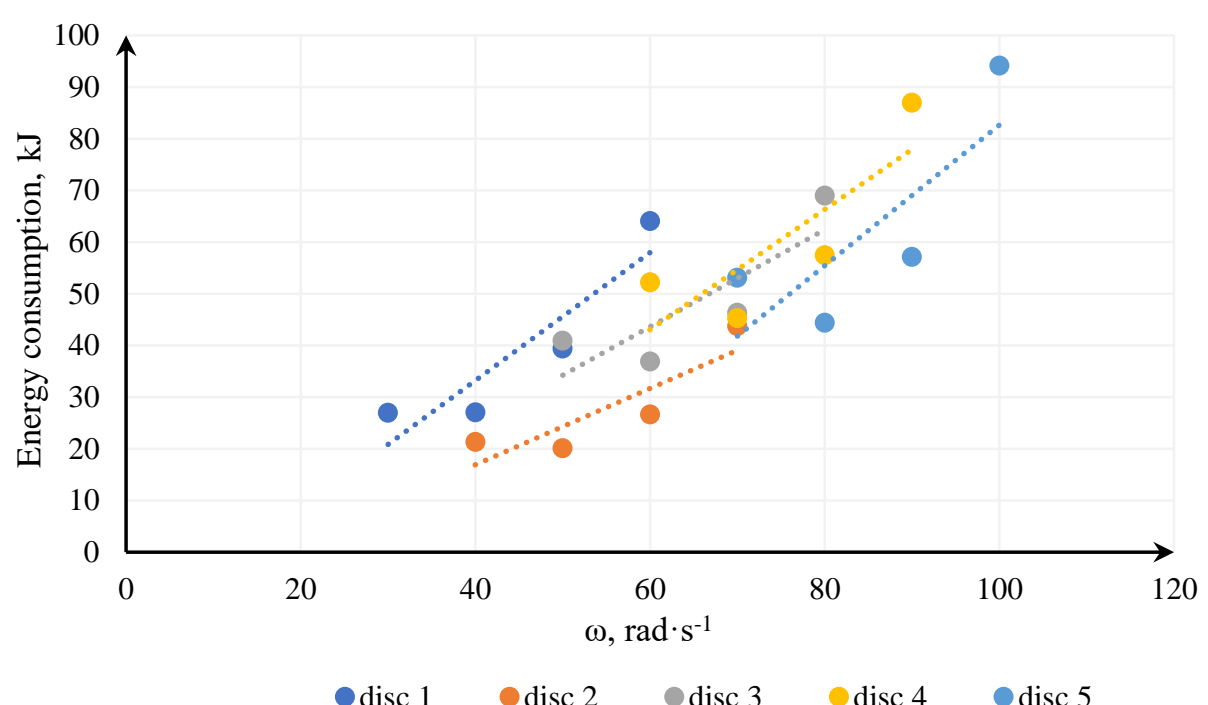

Source: own research

Tab. 3. presents the results of monitoring of specific energy consumption $E_{j}$, real efficiency $Q_{r}$ and grinding degree $i_{80}$ for each disc speed configuration. Considering case $I$, the highest specific energy consumption $E_{j}\left(241151 \mathrm{~J} \cdot \mathrm{kg}^{-1}\right)$ was observed for the first configuration of the disc speed, the lowest for the fourth configuration $\left(152185 \mathrm{~J} \cdot \mathrm{kg}^{-1}\right)$. The highest grinding degree $i_{80}$ for this case was obtained for the first configuration $(1,29)$, the lowest for the fourth configuration $(1,14)$. Real efficiency $Q_{r}$ for case I, was highest for the third disc speed configuration $(14,73 \mathrm{~g} \cdot \mathrm{s}$ $\left.{ }^{1}\right)$, the lowest for the second configuration $\left(12,65 \mathrm{~g} \cdot \mathrm{s}^{-1}\right)$ 


\section{IRSETCONF}

Table 3: Results of monitoring the specific energy consumption, real efficiency and grinding degree for each disc speed configuration

Source: own research

\begin{tabular}{|c|c|c|c|c|}
\hline \multirow{3}{*}{ Case } & $\begin{array}{c}\text { No of } \\
\text { config. }\end{array}$ & $E_{j}$ & $i_{80}$ & $Q_{r}$ \\
\cline { 2 - 5 } & 1 & $\mathrm{~J} \cdot \mathrm{kg}^{-1}$ & - & $\mathrm{g} \cdot \mathrm{s}^{-1}$ \\
\hline \multirow{4}{*}{1} & 2 & 241151 & 1,29 & 14,05 \\
\cline { 2 - 5 } & 3 & 216508 & 1,24 & 12,65 \\
\cline { 2 - 5 } & 4 & 166015 & 1,15 & 14,73 \\
\hline \multirow{4}{*}{ II } & 1 & 152185 & 1,14 & 13,66 \\
\cline { 2 - 5 } & 2 & 358053 & 1,41 & 14,20 \\
\cline { 2 - 5 } & 3 & 486424 & 1,28 & 13,71 \\
\cline { 2 - 5 } & 4 & 467425 & 1,18 & 13,80 \\
\hline
\end{tabular}

Considering case II, the highest specific energy consumption $E_{j}\left(358053 \mathrm{~J} \cdot \mathrm{kg}^{-1}\right)$ was observed for the second configuration of disc speed, the lowest for the fourth configuration (303850 $\left.\mathrm{J} \cdot \mathrm{kg}^{-1}\right)$. The highest grinding degree $i_{80}$ for this case was obtained for the first configuration $(1,41)$, the lowest for the fourth configuration $(1,15)$. Real efficiency $Q_{r}$ for case II was highest for the first disc speed configuration $\left(14,20 \mathrm{~g} \cdot \mathrm{s}^{-1}\right)$, the lowest for the fourth configuration $\left(12,55 \mathrm{~g} \cdot \mathrm{s}^{-1}\right)$. Also the grinding time was longer for case II for the each disc speed configuration.

Comparing the specific energy consumption for each disc speed configuration in two cases, it was found that higher specific energy consumption (almost twice as large) occurred in case II for each configuration (Fig. 6.) than in case I. It was also observed that while the disc angular speed decreases, the specific energy consumption decreases too. Similar effect was observed for other mills ex. impact mills, crushers (Guo et al., 2012; Ismail \& Elhenaway, 2009; Smejtkova \& Vaculik, 2018). Different results was obtained for roller mill with inter roller plate developed by authors (Tomporowski et al., 2017). For that roller mill the specific energy consumption decreases, while the roller speed increases, what was caused by the higher dynamic of efficiency growth than increases in energy demand. 


\section{IRSETCONF}

Figure 6: Specific energy consumption for grinding for each disc speed configuration

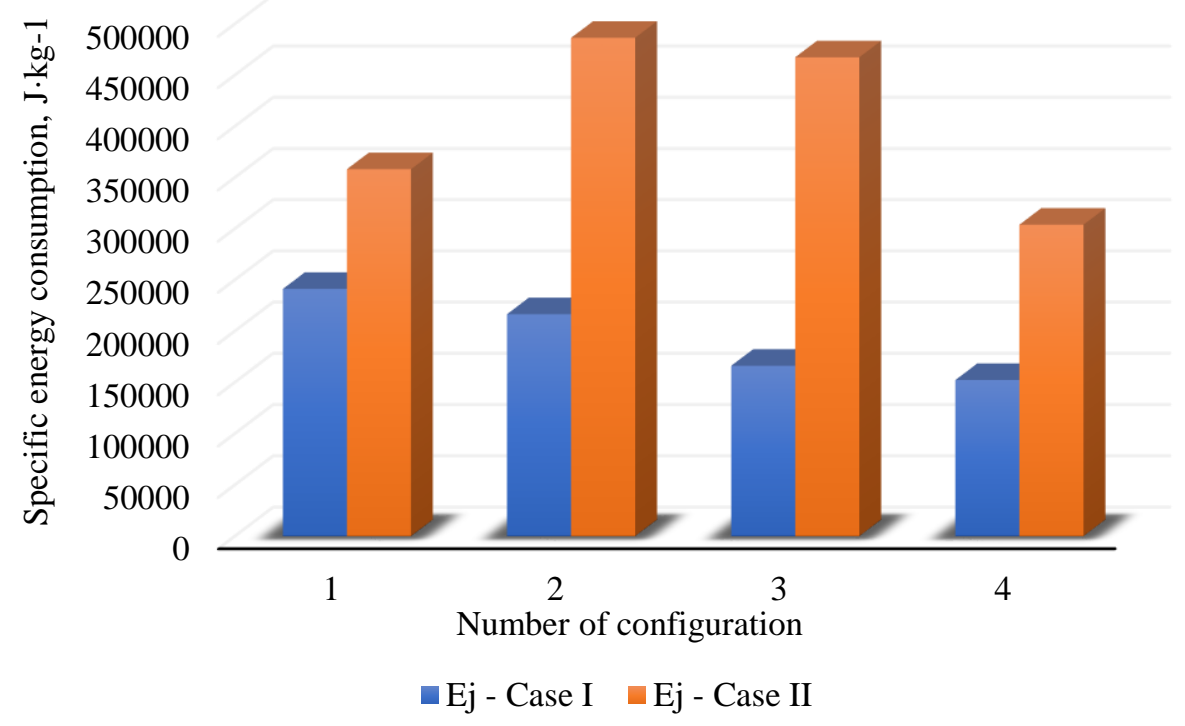

Source: own research

Figure 7: Grinding degree iso for each disc speed configuration

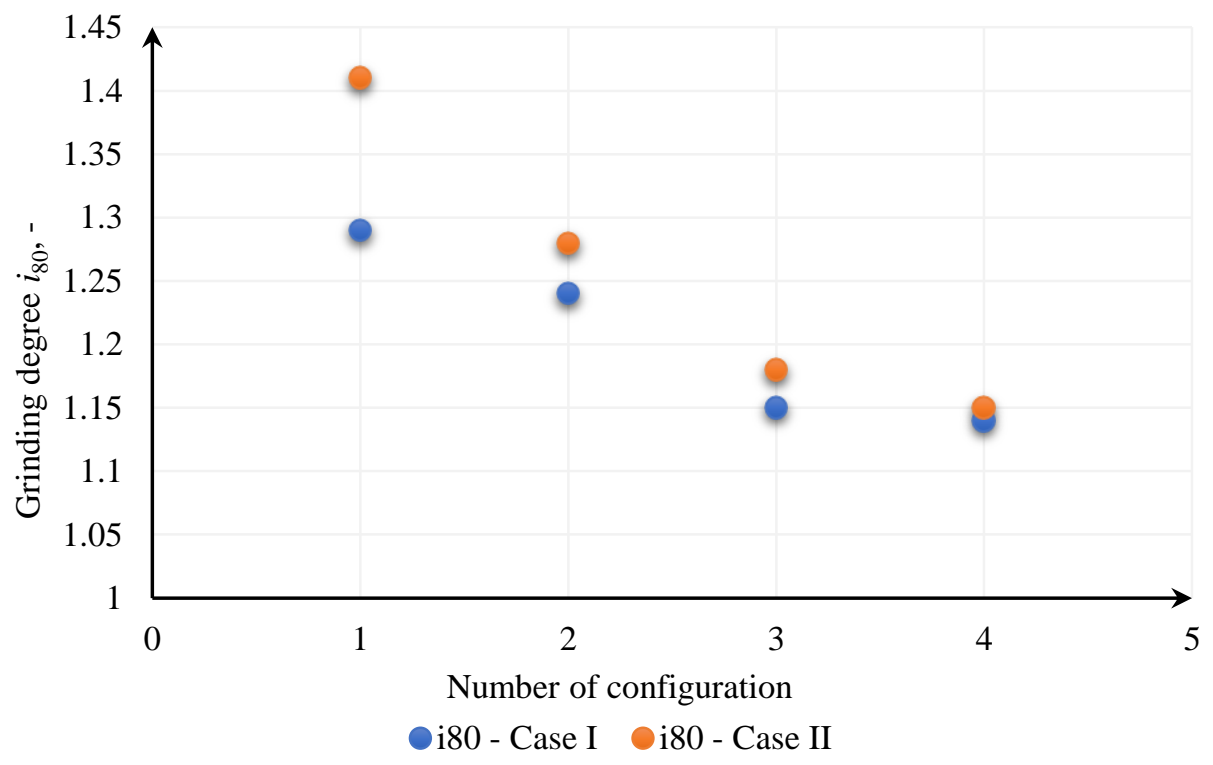

Source: own research 


\section{IRSETCONF}

In turn, considering the grinding degree, it turned out to be higher in case II for each configuration (Fig. 7.) as compared to case I. Similarly as for specific energy consumption, while the disc angular speed decreases, the grinding degree $i_{80}$ decreases too, which is consistent with previously conducted research for disc mills published for example in (Smejtkova \& Vaculik, 2018).

For real efficiency $Q_{r}$, based on the obtained results, the dependence on the angular discs speed cannot be clearly determined (Fig. 8.)

Figure 8: Real efficiency for each disc speed configuration

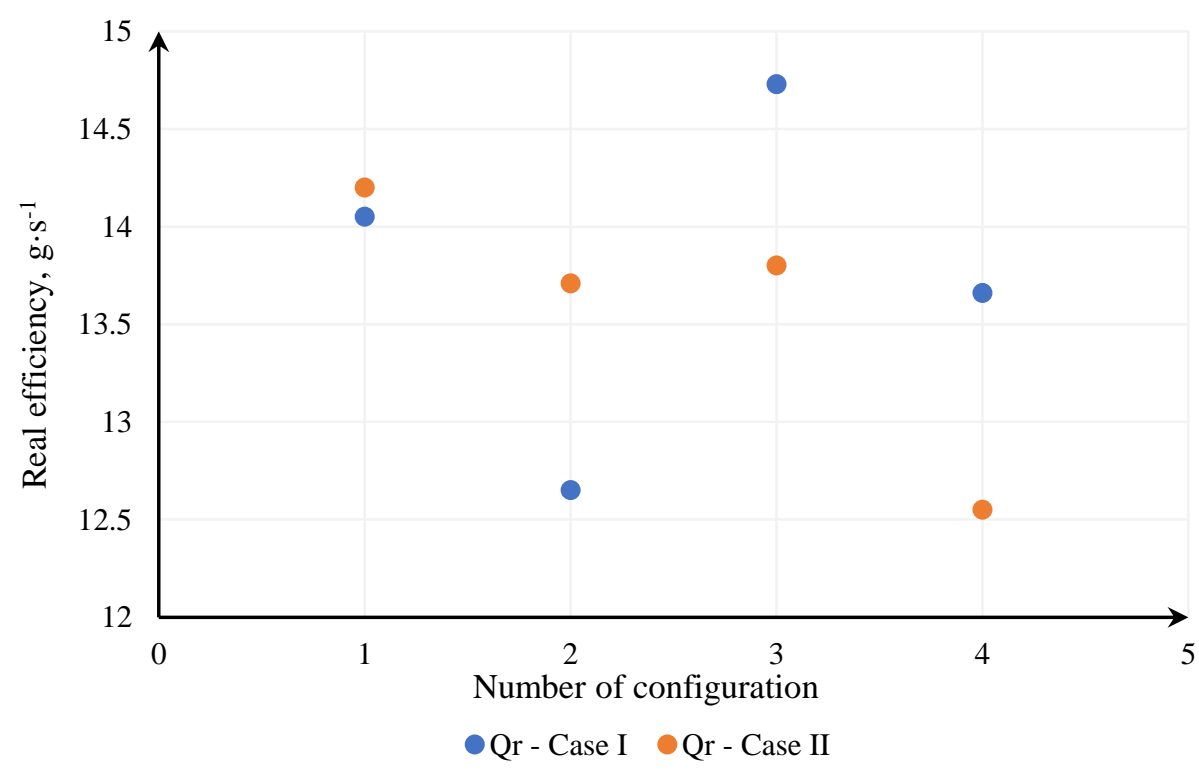

\section{Source: own research}

In the analyzed five-disc mill the first disc has the smallest number of holes with the largest diameter. In each subsequent disc, the number of holes increases and their diameter decreases. Not without significance is the direction of the velocity gradient in the disk assembly, i.e. whether the speed applied will be the highest on the first disc and reduced on successive discs, or vice versa the smallest on the first disc and increased on the following discs. In case the velocity on the discs decreases from disc 1 to 5, the input material is drawn into the inter-disc space and better disintegrated, the motion resistance is also reduced. In the case when the velocities increase from the disc 1 to 5 , the material is repelled from the discs, because the faster and faster elements are a barrier to the material passing through the shredding unit. Then the resistance to movement and energy demand increases and the material is less shredded and retained in the 


\section{IRSETCONF}

interstitial joints. The phenomena occurring in the five-disc unit with such a variable disc design are difficult to describe, especially in the aspect of material flow through the discs and trajectories of its motion. Part of this issue is described in the paper (Tomporowski, 2011). What is important, this observation allows to state that the disc speed in multi disc grinders cannot be selected randomly. The sequence of disc speed is important, especially if the discs structures differ, like in analyzed mill.

\section{Conclusion}

The aim of this work has been achieved through analysis of the rice multi-disc grinding process and determination of a dependence between the cutting edge angular speed and operation indicators such as real efficiency, specific energy consumption and grinding degree. In result of the conducted experiment obtained the answears to the pre-formulated research problem have been obtained:

- as the angular velocity of the discs increases, the energy consumption during grinding increases

- while the disc angular speed decreases, the specific energy consumption decreases too.

- while the disc angular speed decreases, the grinding degree $i_{80}$ decreases too

- for real efficiency $Q_{r}$ the dependence on the angular discs speed cannot be clearly determined.

The conducted experiment proves that not without significance is the direction of the velocity gradient in the disk assembly. This observation allows to state that the disc speed in multi disc grinders cannot be selected randomly. The sequence of disc speed is important, especially if the discs structures differ. According to this, it can be said that grinding unit structure affects significantly on grinding process operational parameters such as real efficiency, specific energy consumption and grinding degree. As a consequence, disc mills and mills at all, should be designed and carefully analyzed using specialized software that allows to simulate the grinding unit and the grinded material movement, eg EDEM Bulk Sim or Rocky DEM. Further research should focus on determining the relationship between the disc design and material flow.

\section{Aknowledgment}

Scientific work financed by the budget resource for science in 2017-2021, as a research project under the "Diamentowy Grant" program. 


\section{IRSETCONF}

\section{References}

[1] Austin, L. G., and Trass, O. (1997). Size Reduction of Solids Crushing and Grinding Equipment. Handbook of Powder Science \& Technology. Boston: Springer, pp. 586-634.

[2] Bergman, P. (2005). Optimisation of fragmentation and comminution at Boliden Mineral, Aitik Operation. Luleå University of Technology [online]. Avaliable: https://www.divaportal.org/smash/get/diva2:989832/FULLTEXT01.pdf

[3] Brożek, M., and Naziemiec, Z. (2012). Analysis of the mechanics of the comminution process of minerals in crushers and high-pressure grinding rolls. Gospodarka Surowcami Mineralnymi, vol. 28, no. 3, pp. 139-153.

[4] Dziki, D., and Laskowski, J. (2005). Influence of selected factors on wheat grinding energy requirements. Teka. Commission of Motorization and Power Industry in Agriculture, vol. 5, pp. 56-64.

[5] Fang, Z., Deng, W., Zhang, Y., Ding, X., Tang, M., Liu, T., ... Wang, X. (2017). Open burning of rice, corn and wheat straws: primary emissions, photochemical aging, and secondary organic aerosol formation. Atmospheric Chemistry and Physics, vol. 17, no. 24, pp. 1482114839.

[6] Flizikowski, J., and Bielinski, K. (2012). Technology and Energy Sources Monitoring: Control, Efficiency, and Optimization. USA: IGI Global.

[7] Flizikowski, J., and Sadkiewicz, J. (2013). Innovation engineering of granular biomass shredders. Chemical Engineering and Equipment, vol. 52, no. 2, pp. 36-37.

[8] Flizikowski, J., Sadkiewicz, J., and Tomporowski, A. (2015). Functional characteristics of a six-roller mill for grainy or particle materials used in chemical and food industries. Przemyst Chemiczny, vol. 94, no. 1, pp. 69-75.

[9] Gil, M. V., García, R., Pevida, C., and Rubiera, F. (2015). Grindability and combustion behavior of coal and torrefied biomass blends. Bioresource Technology, vol. 191, pp. 205212.

[10] Guo, Y., Loenders, J., Duflou, J., and Lauwers, B. (2012). Optimization of Energy Consumption and Surface Quality in Finish Turning. Procedia CIRP, vol. 1, pp. 512-517.

[11] Ismail, Z. E., and Elhenaway, M. N. (2009). Optimization of machine parameters for a sunflower thresher using friction drum. Journal of Agricultural Science of Mansoura University, Vol. 34, no. 10, pp. 10293-10304. 


\section{IRSETCONF}

[12] Johnson, N. W. (2006). Review of Existing Eco-efficient Comminution Devices. The Coalition for Eco-Efficient Comminution (CEEC) Review paper. [online], Avaliable: https://www.ceecthefuture.org/resources/review-of-existing-eco-efficient-comminutiondevices.

[13] Kłos, Z. (2016). Classification and measurement of innovations. Journal of Mechanical and Transport Engineering, vol. 68, no. 4, pp. 27-42.

[14] Liu, X., Liu, S., and Tang, P. (2015). Coal fragment size model in cutting process. Powder Technology, vol. 272, pp. 282-289.

[15] Liu, X., Zhang, M., Hu, N., Yang, H., and Lu, J. (2016). Calculation model of coal comminution energy consumption. Minerals Engineering, vol. 92, pp. 21-27.

[16] Loh, Z. H., Samanta, A. K., \& Sia Heng, P. W. (2015). Overview of milling techniques for improving the solubility of poorly water-soluble drugs. Asian Journal of Pharmaceutical Sciences, vol. 10, no. 4, pp. 255-274

[17] Macko, M., Flizikowski, J., Szczepański, Z., Tyszczuk, K., Śmigielski, G., Mroziński, A., ... Tomporowski, A. (2016). CAD/CAE Applications in Mill's Design and Investigation. Proceedings of the 13th International Scientific Conference. Springer, Cham, pp. 343-351

[18] Dabbour, M. I., Bahnasawy A., Ali, S., and El-Haddad. (2015). Grinding Parameters and their Effects on the Quality of Corn for Feed Processing. Journal of Food Processing \& Technology, vol. 6, no. 9, pp. 1-7.

[19] Mohd Rozalli, N. H., Chin, N. L., and Yusof, Y. A. (2015). Grinding characteristics of Asian originated peanuts (Arachishypogaea L.) and specific energy consumption during ultra-high speed grinding for natural peanut butter production. Journal of Food Engineering, vol. 152, pp. 1-7.

[20] Niedzwiecki, L. (2012). Guide to biomass comminution. Material properties, machinery, principles of the process and fundamentals of process modelling. Hamburg: Bachelor+Master Publishing.

[21] Opielak, M., Jankowski, M., Piasecka, I., and Tomporowski, A. (2013). Analysis of nonuniformity of biomass grinding. Part II. Machine testing. Chemical Engineering and Equipment, vol. 52, no. 2, pp. 44-46.

[22] Opielak, M., and Tomporowski, A. (2012). Structural features versus multi-hole grinding efficiency. Eksploatacja i Niezawodność - Maintenance and Reliability, vol. 14, no 3, pp. 222-227. 


\section{IRSETCONF}

[23] Miu P. I., Woma A. R., Cannayen, I., and Sokhansanj, S. (2006). Analysis of Biomass Comminution and Separation Processes in Rotary Equipment - A Review. ASABE Paper No. 066169 [online]. Available: http://elibrary.asabe.org/abstract.asp?aid=21523\&t=5

[24] Pode, R. (2016). Potential applications of rice husk ash waste from rice husk biomass power plant. Renewable and Sustainable Energy Reviews, vol. 53, pp. 1468-1485.

[25] Shashidhar, M. G., Murthy, T. P. K., Girish, K. G., and Manohar, B. (2013). Grinding of Coriander Seeds: Modeling of Particle Size Distribution and Energy Studies. Particulate Science and Technology, vol. 31, no. 5, pp. 449-457.

[26] Smejtkova, A., and Vaculik, P. (2018). Comparison of power consumption of a two-roll mill and a disc mill. Agronomy Research, vol. 16, no. S2, pp. 1486-1492.

[27] Song, S.-H., Lee, M.-G., Lee, H.-J., and Yoon, W.-B. (2014). Analysis of grinding kinetics to control the effect of rice flour particle size on the yield of alcohol and glucose during fermentation. International Journal of Food Science \& Technology, vol. 49, no. 12, pp. 27032710.

[28] Sykutera, D. (2016). Research on cutting process of selected porous thermoplastics. Chemical Engineering and Equipment, vol. 55, no. 3, pp. 108-109.

[29] Tamura, M., Watanabe, S., Kotake, N., and Hasegawa, M. (2014). Grinding and combustion characteristics of woody biomass for co-firing with coal in pulverised coal boilers. Fuel, vol 134, pp. 544-553.

[30] Tavares, L. M. (2004). Optimum routes for particle breakage by impact. Powder Technology, vol. 142, no. 2, pp. 81-91.

[31] Tomporowski, A. (2010). Research on rice grain grinding usefulness. Part I - testing model. Chemical Engineering and Equipment, vol. 49, no. 5, pp. 119-120.

[32] Tomporowski, A. (2011). Studium efektywności napędu i rozwiqzań innowacyjnych konstrukcji wielotarczowych rozdrabniaczy ziaren biomasy. Lublin: Lubelskie Towarzystwo Naukowe.

[33] Tomporowski, A. (2012). Stream of efficiency of rice grains multi-disc grinding strumień wydajności wielotarczowego rozdrabniania ziaren ryżu. Eksploatacja i Niezawodność Maintenance and Reliability, vol. 14, no. 2, pp. 150-153

[34] Tomporowski, A., Flizikowski, J., and Kruszelnicka, W. (2017). New concept of roller plate mills. Przemys/ Chemiczny, vol. 96, no. 8, pp. 136-141. 